\title{
PENGARUH PERBANDINGAN TERIGU DAN PUREE BUAH NAGA MERAH (Hylocereus polyrhizus) TERHADAP KARAKTERISTIK DONAT
}

\author{
The Effect of Wheat Flour and Puree of Red Dragon Fruit (Hylocereus polyrhizus) \\ Ratio on the Characteristic of Donut
${ }^{1}$ Dinda Tessa Lonika Simbolon, ${ }^{2}$ Putu Timur Ina, M.S. ${ }^{*}{ }^{2}$ Gusti Ayu Kadek Diah Puspawati, S.TP., M.Si.
${ }^{1}$ Mahasiswa Program Studi Ilmu dan Teknologi Pangan, Fakultas Teknologi Pertanian, Unud
${ }^{2}$ Dosen Program Studi Ilmu dan Teknologi Pangan, Fakultas Teknologi Pertanian, Unud Kampus Bukit Jimbaran, Badung-Bali

\begin{abstract}
This research aimed to determine the effect of wheat flour and puree of red dragon fruit ratio on the characteristics of donut and obtain a ratio of wheat flour and puree of red dragon fruit which able to produce donut with the best characteristics. The Completely Randomized Design was used in this researched with the treatment ratio of wheat flour and puree of red dragon fruit which consisted of five levels, such as $100 \%: 0 \%, 90 \%: 10 \%, 80 \%: 20 \%, 70 \%: 30 \%, 60 \%: 40 \%$. The treatment was repeated 3 times to obtain 15 units of experiment. The datas were analyzed by analysis of variance and if the treatment had a significant effect, the Duncan Multiple Range Test were performed. The results showed that ratio of wheat flour and puree of red dragon fruit had a significant effect on water content, anthocyanin content, antioxidant activity, $\left(\mathrm{L}^{*}\right),\left(\mathrm{a}^{*}\right),\left(\mathrm{b}^{*}\right)$, color (hedonic and scoring), texture (hedonic and scoring), tasted (hedonic), and overall acceptance (hedonic) and had no significant effect on odor (hedonic). Ratio of $60 \%$ wheat flour : $40 \%$ puree of red dragon fruit produced the best characteristic of donut, with the following criteria: $23.17 \%$ water content, $12.85 \mathrm{mg} / 100 \mathrm{~g}$ anthocyanin content, $64.58 \%$ antioxidant activity, $31.13\left(\mathrm{~L}^{*}\right), 41.33\left(\mathrm{a}^{*}\right), 14.33\left(\mathrm{~b}^{*}\right)$, very red color and liked, odor and taste liked, very soft texture and liked, and overall acceptance liked.
\end{abstract}

Keywords: wheat, puree of red dragon fruit, donut.

\section{PENDAHULUAN}

Donat merupakan makanan yang dibuat dari terigu melalui proses fermentasi dengan ragi roti dan digoreng. Donat memiliki bentuk yang sangat khas dengan lubang di tengah layaknya seperti cincin dan berbentuk bulat jika diisi oleh suatu bahan (filling). Donat merupakan salah satu jenis makanan yang sangat popular di semua kalangan baik anak-anak, remaja, maupun orang dewasa dan banyak dijual di mal-mal, pasar-pasar dan warung-warung. Pewarnaan pada donat masih monoton dan belum bervariasi sehingga perlu divariasikan dengan warna yang lebih menarik.

Pada makanan, warna mempunyai arti dan peranan yang sangat penting dalam penilaian konsumen. Peranan ini sangat nyata pada 3 hal yaitu sebagai daya tarik, tanda pengenal dan atribut mutu. Warna dalam makanan dapat berasal dari warna alami makanan itu sendiri atau dari bahan pewarna yang ditambahkan ke dalam makanan tersebut. Pewarna makanan terbagi dalam 2 jenis yaitu, pewarna alami dan pewarna sintesis. Pewarna alami dianggap lebih aman dari pewarna sintesis karena pewarna alami

*Korespondensi Penulis:

E-mail: timurina@unud.ac.id 
adalah zat warna (pigmen) yang diperoleh dari buah-buahan, salah satunya dapat diperoleh dari buah naga merah.

Buah naga merah mengandung pigmen alami yaitu antosianin sebanyak 28,7-55,6 mg/100 g (Vargas, et al., 2013). Antosianin merupakan zat warna yang berperan memberikan warna merah, ungu dan biru yang berpotensi sebagai pewarna alami untuk pangan dan dapat dijadikan alternatif pengganti pewarna sintetis yang lebih aman bagi kesehatan (Citramukti, 2008). Buah naga merah juga mengandung zat gizi yang baik sebagai sumber vitamin, dan mineral serta serat pangan pektin yang baik untuk menurunkan kadar kolesterol darah, mencegah penyakit kanker, meningkatkan daya tahan tubuh, menormalkan sistem peredaran darah, menetralkan toksin (racun) dalam tubuh, menurunkan kadar lemak, menjaga kesehatan jantung, memperhalus kulit wajah, dan mengobati sembelit (Cahyono, 2009). Buah naga merah kaya dengan vitamin C, vitamin B1, vitamin B2 dan vitamin B3 serta mineral fosfor dan besi (Farikha, 2013). Antosianin yang ada pada buah naga merah juga dapat berfungsi sebagai antioksidan.

Donat dapat dibuat dengan penambahan sayuran dan buah-buahan berwarna. Hal ini dapat diketahui dari penelitian Shahrirputra (2019) yang melaporkan bahwa donat dengan perbandingan terigu dan pasta brokoli (60\%:40\%) dapat menghasilkan karakteristik donat terbaik. Agustin (2017) juga melaporkan bahwa kue lumpur dengan perbandingan terigu dan puree labu kuning (70\%:30\%) dapat menghasilkan karakteristik kue lumpur terbaik.
Karakteristik donat dapat dipengaruhi dari perbandingan terigu dan puree buah naga merah. Terigu berfungsi membentuk struktur donat karena glutennya berguna untuk mengembangkan adonan sehingga donat menjadi empuk (Astawan, 2006) dan penambahan puree buah naga merah dapat memperbaiki tampilan warna donat, membuat tekstur lebih baik dan meningkatkan nilai gizi donat.

Perbandingan terigu dan puree buah naga merah belum pernah dilaporkan. Berdasarkan hal tersebut, perlu dilakukan penelitian tentang pengaruh perbandingan terigu dan puree buah naga merah (Hylocereus polyrhizus) terhadap karakteristik donat.

\section{METODE PENELITIAN}

\section{Tempat dan Waktu}

Penelitian ini dilaksanakan di Laboratorium Pengolahan Pangan, Laboratorium Analisis Pangan, Laboratorium Pasca Panen, dan Laboratorium Rekayasa Proses dan Pengendalian Mutu, Fakultas Teknologi Pertanian, Universitas Udayana. Penelitian ini dilakukan pada bulan Agustus - September 2019.

\section{Bahan dan Alat}

Bahan yang digunakan dalam penelitian ini adalah buah naga merah yang sudah matang dan terigu (Cakra Kembar) yang diperoleh di Pasar Jimbaran, telur ayam ras, ragi (Fermipan), gula (Gulaku), margarin (forVita), minyak goreng (Bimoli) yang diperoleh di toko Kurnia Puri Gading Jimbaran. Bahan kimia yang digunakan pada penelitian ini adalah aquades (Shagufta Laboratory), metanol PA (Merck), heksan, HCl PA 
(Merck), buffer pH 1 (Merck), buffer pH 4,5 (Merck) dan 1-diphenyl-2picrylhydrazil (DPPH) (Sma Aldrich).

Alat-alat yang digunakan dalam penelitian ini adalah blender (Phlips), meja, kompor gas (Rinnai), pisau, loyang, waskom, sendok makan, cetakan donat, kain basah, termometer minyak goreng, timbangan digital (ACIS), roolpan, dan wajan penggorengan. Alat yang digunakan untuk analisis adalah timbangan analitik (Shimadzu), oven (Blue M), erlenmeyer, tabung reaksi, soxhlet (Behrotest), kertas saring, corong, pipet tetes, labu ukur, tip, vortex (Barnstead Thermolyne Type 37600 mixer), spektrofotometer (Genesys 10S Uv-Vis), sentrifuse, botol kaca, gelas beker, pipet mikro, desikator, aluminium foil, cawan, penjepit.

\section{Rancangan Penelitian}

Rancangan yang digunakan pada penelitian ini adalah Rancangan Acak Lengkap (RAL) yang terdiri dari 5 perlakuan perbandingan terigu dan puree buah naga merah yaitu: $\mathrm{P} 0=0 \%$ : 100\%, P1 = 10\%: 90\%, P2 = 20\%: $80 \%$, P3 $=30 \%: 70 \%$, P4 $=40 \%$ : $60 \%$. Masing-masing perlakuan diulang sebanyak 3 kali sehingga diperoleh 15 unit percobaan. Data yang diperoleh dianalisis dengan sidik ragam, apabila perlakuan berpengaruh, maka dilanjutkan dengan uji Duncan (Gomez dan Gomez, 1995).

\section{Pelaksanaan Penelitian}

Proses pembuatan donat perbandingan terigu dan puree buah naga merah meliputi beberapa tahap, yaitu:

\section{Pembuatan puree buah naga merah}

Buah naga merah yang masih utuh disortasi terlebih dahulu dan dicuci dengan air bersih lalu dibelah menjadi 4 bagian dan daging buah dipisahkan dari kulitnya. Daging buah lalu dihancurkan menggunakan blender.

\section{Pembuatan biang}

Ragi sebanyak 2 gram ditambahkan dengan 2 gram gula pasir lalu dicampurkan dengan $10 \mathrm{ml}$ air yang bersuhu $30^{\circ} \mathrm{C}$, kemudian didiamkan dengan ditutup kain basah selama 5 menit.

\section{Pembuatan donat}

Tahap pembuatan donat diawali dengan terigu (sesuai perlakuan), gula pasir dan biang dicampurkan kemudian diaduk, lalu dimasukkan kuning telur dan puree buah naga merah (sesuai perlakuan) kemudian diuleni selama 10 menit, setelah itu dimasukkan margarin dan diuleni sampai adonan kalis. Setelah kalis adonan ditutup dengan kain basah dan didiamkan selama 1 jam. Adonan yang sudah mengembang dikempiskan lalu dibagi adonan dan ditimbang sebanyak 30 gram. Adonan dibentuk bulat kemudian digiling menggunakan roolpan dan dicetak menggunakan cetakan donat. Adonan yang telah dicetak diletakan pada loyang dan didiamkan kembali selama 10 menit dengan ditutup kain basah. Selanjutnya, adonan digoreng menggunakan minyak goreng dengan suhu $190^{\circ} \mathrm{C}$ selama \pm 2 menit.

Formula pembuatan donat menurut Shahrirputra (2019) yang dimodifikasi dapat dilihat pada Tabel 1 .

\section{Variabel yang Diamati}

Variabel yang diamati pada penelitian ini meliputi: kadar air dengan metode pengeringan (AOAC, 2006), aktivitas antioksidan menggunakan metode DPPH (Shah 
dan Modi, 2015), total antosianin dengan metode $\mathrm{pH}$ differensial (Lee, 2005), nilai $L^{*}, a^{*}, b^{*}$ menggnakan aplikasi colorimeter dengan bantuan smartphone merk OPPO F3, dan sifat sensoris diuji dengan uji hedonik (warna, tekstur, aroma, rasa dan penerimaan keseluruhan) dan uji skor (tekstur dan warna) (Soekarto, 1985).

Tabel 1. Formula donat perbandingan terigu dan puree buah naga merah

\begin{tabular}{|c|c|c|c|c|c|c|}
\hline \multirow{2}{*}{ No } & \multirow{2}{*}{ Komposisi } & \multicolumn{5}{|c|}{ Perlakuan } \\
\hline & & $\mathrm{P} 0$ & $\mathrm{P} 1$ & $\mathrm{P} 2$ & P3 & $\mathrm{P} 4$ \\
\hline 1 & Terigu $(\%)$ & 100 & 90 & 80 & 70 & 60 \\
\hline 2 & Puree buah naga merah (\%) & 0 & 10 & 20 & 30 & 40 \\
\hline 3 & Kuning telur (\%) & 20 & 20 & 20 & 20 & 20 \\
\hline 4 & Gula pasir (\%) & 12 & 12 & 12 & 12 & 12 \\
\hline 5 & Margarin $(\%)$ & 20 & 20 & 20 & 20 & 20 \\
\hline 6 & Biang (\%) & 10 & 10 & 10 & 10 & 10 \\
\hline
\end{tabular}

Keterangan : \% bahan-bahan diatas dihitung berdasarkan jumlah terigu dan puree buah naga merah $(100 \mathrm{~g})$

\section{HASIL DAN PEMBAHASAN}

Hasil analisis kadar air, total antosianin, dan aktivitas antioksidan dari bahan baku terigu dan puree buah naga merah ditunjukkan pada Tabel 2.
Nilai rata-rata kadar air, total antosianin, dan aktivitas antioksidan pada donat perbandingan terigu dan puree buah naga merah dapat dilihat pada Tabel 3

Tabel 2. Nilai rata-rata kadar air, total antosianin, dan aktivitas antioksidan dari bahan baku terigu dan puree buah naga merah

\begin{tabular}{lcc}
\hline \multicolumn{1}{c}{ Komponen } & Terigu & Puree buah naga merah \\
\hline Kadar Air $(\%)$ & 13,44 & 83,68 \\
Total Antosianin $(\mathrm{mg} / 100 \mathrm{~g})$ & - & 22,23 \\
Aktivitas Antioksidan $(\%)$ & - & 72,54 \\
\hline
\end{tabular}

Keterangan : Tanda (-) menandakan tidak dilakukan analisis

Tabel 3. Nilai rata-rata kadar air, total antosianin, dan aktivitas antioksidan donat perbandingan terigu dan puree buah naga merah

\begin{tabular}{lccc}
\hline $\begin{array}{c}\text { Terigu : Puree buah } \\
\text { naga merah }\end{array}$ & Kadar Air (\%) & $\begin{array}{c}\text { Total Antosianin } \\
(\mathrm{mg} / 100 \mathrm{~g})\end{array}$ & $\begin{array}{c}\text { Aktivitas } \\
\text { Antioksidan } \\
(\%)\end{array}$ \\
\hline P0 $(100 \%: 0 \%)$ & $18,67 \pm 0,22 \mathrm{~d}$ & $0,00 \pm 0,00 \mathrm{e}$ & $0,00 \pm 0,00 \mathrm{e}$ \\
P1 $(90 \%: 10 \%)$ & $19,25 \pm 0,25 \mathrm{~d}$ & $5,65 \pm 0,27 \mathrm{~d}$ & $28,57 \pm 0,98 \mathrm{~d}$ \\
P2 $(80 \%: 20 \%)$ & $20,60 \pm 0,32 \mathrm{c}$ & $6,55 \pm 0,16 \mathrm{c}$ & $40,99 \pm 1,58 \mathrm{c}$ \\
P3 (70\%:30\%) & $21,71 \pm 0,40 \mathrm{~b}$ & $8,30 \pm 0,09 \mathrm{~b}$ & $57,33 \pm 1,15 \mathrm{~b}$ \\
P4 (60\%: $40 \%)$ & $23,17 \pm 0,47 \mathrm{a}$ & $12,85 \pm 0,30 \mathrm{a}$ & $64,58 \pm 0,91 \mathrm{a}$ \\
\hline
\end{tabular}

Keterangan: Huruf yang sama dibelakang nilai rata-rata pada kolom yang sama menunjukkan berbeda tidak nyata $(\mathrm{P}>0,05)$ 


\section{Kadar Air}

Hasil sidik ragam menunjukkan bahwa perbandingan terigu dan puree buah naga merah berpengaruh nyata $(\mathrm{P}<0,05)$ terhadap kadar air donat. Tabel 10 menunjukkan nilai rata-rata kadar air donat perbandingan terigu dan puree buah naga merah berkisar antara $18,67 \%-23,17 \%$. Nilai rata-rata kadar air tertinggi terdapat pada P4 yaitu $23,17 \%$ dan nilai rata-rata kadar air terendah terdapat pada P0 yaitu 18,67\%. Hal ini menunjukkan bahwa semakin tinggi konsentrasi penambahan puree buah naga merah, maka kadar air donat semakin meningkat. Hal ini disebabkan kadar air pada puree buah naga merah lebih tinggi dibandingkan dengan kadar air terigu. Tabel 9 menunjukkan nilai kadar air puree buah naga merah sebesar 83,68\% sedangkan kadar air terigu sebesar $13,44 \%$.

Kadar air dalam suatu bahan makanan sangat mempengaruhi kualitas dan daya simpan dari bahan pangan tersebut. Kadar air yang tinggi menyebabkan kerentanan terhadap aktivitas mikroba karena kandungan air dalam bahan pangan merupakan media tumbuhnya kapang dan jamur

\section{Total Antosianin}

Hasil sidik ragam menunjukkan bahwa perbandingan terigu dan puree buah naga merah berpengaruh nyata $(\mathrm{P}<0,05)$ terhadap total antosianin donat. Tabel 10 menunjukkan nilai rata-rata total antosianin donat perbandingan terigu dan puree buah naga berkisar antara $0,00 \mathrm{mg} / 100 \mathrm{~g}$ $12,85 \mathrm{mg} / 100 \mathrm{~g}$. Nilai rata-rata total antosianin tertinggi terdapat pada $\mathrm{P} 4$ yaitu $12,85 \mathrm{mg} / 100 \mathrm{~g}$ dan nilai rata-rata total antosianin terendah terdapat pada P0 yaitu $0,00 \mathrm{mg} / 100 \mathrm{~g}$.
Peningkatan total antosianin donat disebabkan karena adanya perbedaan perlakuan terigu dan puree buah naga merah yang ditambahkan. Tabel 9 menunjukkan bahwa pada puree buah naga merah terdapat senyawa antosianin yang tidak dimiliki oleh terigu, sehingga semakin tinggi konsentrasi penambahan puree buah naga merah maka total antosianin donat akan semakin meningkat. Kadar antosianin puree buah naga merah yang sudah diuji mendapatkan nilai rata-rata yaitu $22,23 \mathrm{mg} / 100 \mathrm{~g}$.

\section{Aktivitas Antioksidan}

Hasil sidik ragam menunjukkan bahwa perbandingan terigu dan puree buah naga merah berpengaruh nyata $(\mathrm{P}<0,05) \quad$ terhadap aktivitas antioksidan donat. Tabel 10 menunjukkan nilai rata-rata aktivitas antioksidan donat perbandingan terigu dan puree buah naga merah berkisar antara $0,00 \%-64,58 \%$. Nilai rata-rata aktivitas antioksidan tertinggi terdapat pada $\mathrm{P} 4$ yaitu $64,58 \%$ dan nilai ratarata aktivitas antioksidan terendah terdapat pada P0 yaitu sebesar $0,00 \%$. Data tersebut menunjukkan bahwa semakin tinggi perbandingan terigu dan puree buah naga merah maka aktivitas antioksidan donat semakin meningkat. Hasil ini selaras dengan total antosianinnya karena aktivitas antioksidan pada donat berasal dari antosianin puree buah naga merah. Antosianin merupakan senyawa turunan polifenol yang termasuk kedalam golongan flavonoid dan memiliki fungsi sebagai antioksidan. Kemampuan antosianin sebagai antioksidan karena mampu mendonorkan elektron kepada senyawa radikal bebas (Ridho, 2013).

$\mathrm{IC}_{50}$ dapat ditentukan dari aktivitas antioksidan terbaik sampel 
dan didefinisikan sebagai konsentrasi sampel yang dibutuhkan untuk menghambat $50 \%$ radikal bebas DPPH. Dari hasil perhitungan yang sudah dilakukan, diperoleh nilai $\mathrm{IC}_{50}$,yaitu 113,776,66 ppm dan tergolong sangat lemah karena memiliki nilai $\mathrm{IC}_{50}>200 \mathrm{ppm}$. Suatu senyawa memiliki antioksidan sangat kuat apabila nilai $\mathrm{IC}_{50}$ kurang dari 50 ppm, antioksidan kuat apabila nilai $\mathrm{IC}_{50}$ antara 50-100 ppm, antioksidan sedang apabila nilai $\mathrm{IC}_{50}$ berkisar antara 100-150 ppm, antioksidan lemah apabila nilai $\mathrm{IC}_{50}$ berkisar antara
150-200 ppm, dan apabila nilai $\mathrm{IC}_{50}$ diatas 200 maka termasuk kedalam antioksidan sangat lemah (Molyneux, 2004).

Nilai L*, a*, b*

Hasil sidik ragam menunjukkan bahwa perlakuan perbandingan terigu dan puree buah naga merah berpengaruh nyata $(\mathrm{P}<0,05)$ terhadap nilai $\mathrm{L}^{*}, \mathrm{a}^{*}, \mathrm{~b}^{*}$ donat. Nilai rata-rata $\mathrm{L}^{*}, \mathrm{a}^{*}, \mathrm{~b}^{*}$ pada donat perbandingan terigu dan puree buah naga merah dapat dilihat pada Tabel 4.

Tabel 4. Nilai rata-rata $\mathrm{L}^{*}, \mathrm{a}^{*}, \mathrm{~b}^{*}$ donat perbandingan terigu dan puree buah naga merah

\begin{tabular}{cccc}
\hline Terigu : Puree buah & \multicolumn{3}{c}{ Nilai $\mathrm{L}^{*}, \mathrm{a}^{*}, \mathrm{~b}^{*}$} \\
\cline { 2 - 4 } naga merah & $\mathrm{L}^{*}$ & $\mathrm{a}^{*}$ & $\mathrm{~b}^{*}$ \\
\hline P0 $(100 \%: 0 \%)$ & $53,30 \pm 1,49 \mathrm{a}$ & $5,40 \pm 1,47 \mathrm{c}$ & $58,93 \pm 0,92 \mathrm{a}$ \\
P1 $(90 \%: 10 \%)$ & $48,83 \pm 0,55 \mathrm{~b}$ & $24,36 \pm 2,37 \mathrm{~b}$ & $22,83 \pm 0,80 \mathrm{~b}$ \\
P2 $(80 \%: 20 \%)$ & $42,70 \pm 0,40 \mathrm{c}$ & $39,16 \pm 0,55 \mathrm{a}$ & $18,96 \pm 0,37 \mathrm{c}$ \\
P3 $(70 \%: 30 \%)$ & $31,96 \pm 0,25 \mathrm{~d}$ & $41,16 \pm 1,85 \mathrm{a}$ & $17,06 \pm 1,35 \mathrm{c}$ \\
P4 $(60 \%: 40 \%)$ & $31,13 \pm 1,10 \mathrm{~d}$ & $41,33 \pm 1,05 \mathrm{a}$ & $14,33 \pm 1,59 \mathrm{~d}$ \\
\hline
\end{tabular}

Keterangan: Huruf yang sama dibelakang nilai rata-rata pada kolom yang sama menunjukkan berbeda tidak nyata $(\mathrm{P}>0,05)$

\section{a. Nilai L* (lightness)}

Nilai L* menyatakan tingkat kecerahan yang akan mempengaruhi gelap atau terangnya suatu bahan dengan warna akromatik hitam dan putih. Nilai $L^{*}$ rata-rata donat perbandingan terigu dan puree buah naga merah berkisar antara 53,3031,13. Nilai $\mathrm{L}^{*}$ tertinggi diperoleh dari P0 yaitu sebesar 53,30 dan nilai $L^{*}$ terendah diperoleh dari $\mathrm{P} 4$ yaitu sebesar 31,13 . Tingkat kecerahan yang semakin rendah disebabkan karena konsentrasi penambahan puree buah naga merah yang semakin tinggi. Puree buah naga merah dapat mempengaruhi tingkat kecerahan donat semakin rendah karena puree buah naga merah mengandung senyawa antosianin yang memberikan warna merah pada donat.

\section{b. Nilai a* (redness)}

Nilai a* menyatakan tingkat kemerahan suatu bahan dengan warna kromatik campuran merah dan hijau. Semakin tinggi nilai a*, maka semakin merah warna produk yang dianalisis. Nilai a* rata-rata donat perbandingan terigu dan puree buah naga merah berkisar antara 5,40-41,33. Nilai a* tertinggi diperoleh dari P4 yaitu sebesar 41,33 dan nilai $a^{*}$ terendah diperoleh dari P0 yaitu sebesar 5,40. 
Warna merah pada donat dihasilkan dari puree buah naga merah karena adanya pigmen merah yang berasal dari senyawa antosianin, sehingga semakin tinggi konsentrasi penambahan puree buah naga merah, maka semakin merah warna donat yang dihasilkan, hal ini sesuai dengan uji warna (skoring) pada Tabel 6.

\section{c. Nilai b* (yellowness)}

Nilai $b^{*}$ menyatakan tingkat kekuningan suatu bahan dengan warna kromatik campuran kuning dan biru. Semakin tinggi nilai $b^{*}$, maka semakin kuning warna produk yang dianalisis. Nilai $b^{*}$ rata-rata donat perbandingan terigu dan puree buah naga merah berkisar antara 58,93-14,33. Nilai b* tertinggi diperoleh dari P0 yaitu sebesar 58,93 dan nilai $b^{*}$ terendah diperoleh dari P4 yaitu sebesar 14,33. Warna kuning pada donat dihasilkan dari terigu karena adanya pigmen orange kekuningan yaitu karotenoid. Semakin tinggi konsentrasi penambahan puree buah naga merah, maka semakin rendah tingkat kekuningan donat yang dihasilkan. Hal ini disebabkan karena puree buah naga merah memiliki senyawa antosianin yang memberikan warna merah pada donat.

\section{Sifat Sensoris}

Evaluasi sifat sensoris donat perbandingan terigu dan puree buah naga merah dilakukan dengan uji hedonik terhadap warna, tekstur, aroma, rasa, dan penerimaan keseluruhan serta uji skoring terhadap warna dan tekstur donat. Nilai ratarata uji hedonik terhadap warna, tekstur, aroma, rasa, dan penerimaan keseluruhan donat dapat dilihat pada Tabel 5 dan nilai rata-rata uji skoring terhadap warna dan tekstur donat dapat dilihat pada Tabel 6.

Tabel 5. Nilai rata-rata uji hedonik warna, tekstur, aroma, rasa, dan penerimaan keseluruhan donat perbandingan terigu dan puree buah naga merah

\begin{tabular}{cccccc}
\hline $\begin{array}{c}\text { Terigu : } \\
\text { Puree } \\
\text { Buah Naga } \\
\text { Merah }\end{array}$ & Warna & Aroma & Rasa & Tekstur & $\begin{array}{c}\text { Penerimaan } \\
\text { Keseluruhan }\end{array}$ \\
\hline P0(100\%: & $4,53 \pm 1,55$ & $4,93 \pm 1,03$ & $4,13 \pm 1,24$ & $3,33 \pm 1,54$ & $4,13 \pm 1,30$ \\
$0 \%)$ & $\mathrm{c}$ & & $\mathrm{b}$ & $\mathrm{b}$ & $\mathrm{c}$ \\
$\mathrm{P} 1(90 \%:$ & $4,86 \pm 0,74$ & $5,26 \pm 0,88$ & $4,66 \pm 0,97$ & $5,13 \pm 1,12$ & $4,86 \pm 0,91$ \\
$10 \%)$ & $\mathrm{bc}$ & & $\mathrm{b}$ & $\mathrm{a}$ & $\mathrm{b}$ \\
$\mathrm{P} 2(80 \%:$ & $5,46 \pm 1,18$ & $5,46 \pm 0,83$ & $5,53 \pm 0,63$ & $5,60 \pm 0,91$ & $5,46 \pm 0,74$ \\
$20 \%)$ & $\mathrm{ab}$ & & $\mathrm{a}$ & $\mathrm{a}$ & $\mathrm{ab}$ \\
$\mathrm{P} 3(70 \%:$ & $6,00 \pm 0,65$ & $5,60 \pm 0,73$ & $5,66 \pm 0,97$ & $5,66 \pm 0,61$ & $5,93 \pm 0,96$ \\
$30 \%)$ & $\mathrm{a}$ & & $\mathrm{a}$ & $\mathrm{a}$ & $\mathrm{a}$ \\
$\mathrm{P} 4(60 \%:$ & $6,20 \pm 0,77$ & $5,86 \pm 0,63$ & $5,80 \pm 0,67$ & $5,86 \pm 0,83$ & $6,06 \pm 0,88$ \\
$40 \%)$ & $\mathrm{a}$ & & $\mathrm{a}$ & $\mathrm{a}$ & $\mathrm{a}$ \\
\hline
\end{tabular}

Keterangan: Huruf yang sama dibelakang nilai rata-rata pada kolom yang sama menunjukkan perlakuan berbeda tidak nyata $(\mathrm{P}>0,05)$ 
Tabel 6. Nilai rata-rata uji skoring warna dan tekstur donat perbandingan terigu dan puree buah naga merah

\begin{tabular}{lcc}
\hline \multirow{2}{*}{ Terigu : Puree Buah Naga Merah } & \multicolumn{2}{c}{ Nilai Rata-Rata Uji Skoring } \\
\cline { 2 - 3 } & Warna & Tekstur \\
\hline P0 $(100 \%: 0 \%)$ & $1,00 \pm 0,00 \mathrm{e}$ & $1,80 \pm 0,86 \mathrm{c}$ \\
P1 $(90 \%: 10 \%)$ & $2,73 \pm 0,70 \mathrm{~d}$ & $3,53 \pm 0,83 \mathrm{~b}$ \\
P2 $(80 \%: 20 \%)$ & $3,46 \pm 0,64 \mathrm{c}$ & $4,00 \pm 0,65 \mathrm{ab}$ \\
P3 $(70 \%: 30 \%)$ & $4,33 \pm 0,62 \mathrm{~b}$ & $3,93 \pm 0,89 \mathrm{ab}$ \\
P4 $(60 \%: 40 \%)$ & $4,80 \pm 0,41 \mathrm{a}$ & $4,40 \pm 0,73 \mathrm{a}$ \\
\hline
\end{tabular}

Keterangan: Huruf yang sama dibelakang nilai rata-rata pada kolom yang sama menunjukkan berbeda tidak nyata $(\mathrm{P}>0,05)$

\section{Warna}

Berdasarkan hasil sidik ragam, perbandingan terigu dan puree buah naga merah berpengaruh nyata $(\mathrm{P}<0,05)$ terhadap kesukaan warna donat. Tabel 5 menunjukkan nilai ratarata kesukaan panelis terhadap warna (hedonik) berkisar antara 4,53 (agak suka) sampai dengan 6,20 (suka). Nilai rata-rata kesukaan warna (hedonik) tertinggi donat terdapat pada $\mathrm{P} 4$ yaitu 6,20 (suka) dan nilai rata-rata terendah terdapat pada P0 yaitu 4,53 (agak suka).

Tabel 6 menunjukkan nilai ratarata penilaian panelis terhadap warna (skoring) berkisar antara 1 (tidak merah) sampai dengan 4,8 (sangat merah). Nilai rata-rata penilaian warna (skoring) tertinggi donat terdapat pada P4 yaitu 4,8 (sangat merah), sedangkan nilai rata-rata penilaian warna (skoring) terendah donat terdapat pada P0 yaitu 1 (tidak merah). Hal ini sesuai dengan uji total antosianin (Tabel 3) dan uji nilai a* (Tabel 4) yang menunjukkan semakin tinggi konsentrasi penambahan puree buah naga merah, maka warna donat semakin merah. Hal ini dapat disebabkan karena puree buah naga merah mengandung zat warna alami antosianin yang berperan memberikan warna merah dan dapat dijadikan alternatif pengganti pewarna sintesis yang lebih aman bagi kesehatan (Citramukti, 2008).

\section{Aroma}

Berdasarkan hasil sidik ragam, perbandingan terigu dan puree buah naga merah berpengaruh nyata $(\mathrm{P}>0,05)$ terhadap kesukaan aroma donat. Tabel 5 menunjukkan nilai ratarata kesukaan panelis terhadap aroma berkisar antara 4,93 (agak suka) sampai dengan 5,86 (suka). Nilai ratarata kesukaan aroma tertinggi donat terdapat pada P4 yaitu 5,86 (suka) dan nilai rata-rata terendah terdapat pada P0 yaitu 4,93 (agak suka).

\section{Rasa}

Berdasarkan hasil sidik ragam, perbandingan terigu dan puree buah naga merah berpengaruh nyata $(\mathrm{P}<0,05)$ terhadap kesukaan rasa donat. Tabel 5 menunjukkan nilai ratarata kesukaan panelis terhadap rasa berkisar antara 4,13 (biasa) sampai dengan 5,80 (suka). Nilai rata-rata kesukaan rasa tertinggi donat terdapat pada P4 yaitu 5,80 (suka) dan nilai rata-rata terendah terdapat pada $\mathrm{P} 0$ yaitu 4,13 (biasa).

\section{Tekstur}

Berdasarkan hasil sidik ragam, perbandingan terigu dan puree buah naga merah berpengaruh nyata 
$(\mathrm{P}<0,05)$ terhadap kesukaan tekstur donat. Tabel 5 menunjukkan nilai ratarata kesukaan panelis terhadap tekstur (hedonik) berkisar antara 3,33 (agak tidak suka) sampai dengan 5,86 (suka). Nilai rata-rata kesukaan tekstur (hedonik) tertinggi donat terdapat pada P4 yaitu 5,86 (suka) dan nilai rata-rata terendah terdapat pada P0 yaitu 3,33 (agak tidak suka).

Tabel 6 menunjukkan nilai ratarata penilaian panelis terhadap tekstur (skoring) berkisar antara 1,8 (agak lembut) sampai dengan 4,4 (sangat lembut). Nilai rata-rata penilaian tekstur (skoring) tertinggi donat terdapat pada P4 yaitu 4,4 (sangat lembut) dan nilai rata-rata terendah terdapat pada P0 yaitu 1,8 (agak lembut). Hal ini sesuai dengan uji kadar air donat perbandingan terigu dan puree buah naga merah (Tabel 3) yang menunjukkan semakin tinggi konsentrasi penambahan puree buah naga merah, maka kadar air donat semakin meningkat dan mempengaruhi tekstur donat menjadi sangat lembut.

\section{Penerimaan Keseluruhan}

Berdasarkan hasil sidik ragam, perbandingan terigu dan puree buah naga merah berpengaruh nyata $(\mathrm{P}<0,05)$ terhadap penerimaan keseluruhan donat. Tabel 5 menunjukkan nilai rata-rata kesukaan panelis terhadap penerimaan keseluruhan donat berkisar antara 4,13 (biasa) sampai dengan 6,06 (suka). Nilai rata-rata penerimaan keseluruhan tertinggi yaitu 6,06 (suka) pada konsentrasi penambahan puree buah naga merah sebesar $40 \%$. Hal ini menunjukkan bahwa produk donat perbandingan $60 \%$ terigu : $40 \%$ puree buah naga merah pada penelitian ini lebih disukai dibandingkan dengan perlakuan yang lain. Penerimaan keseluruhan tersebut dipengaruhi oleh beberapa faktor seperti warna, aroma, rasa, dan tekstur dari produk pada masing- masing perlakuan dan bersifat subjektif.

\section{KESIMPULAN DAN SARAN}

\section{Kesimpulan}

Berdasarkan hasil penelitian yang telah dilakukan dapat diambil kesimpulan sebagai berikut:

1. Perbandingan terigu dan puree buah naga merah berpengaruh nyata terhadap kadar air, total antosianin, aktivitas antioksidan, nilai $\mathrm{L}^{*}, \mathrm{a}^{*}$, $\mathrm{b}^{*}$, warna (hedonik dan skoring), tekstur (hedonik dan skoring), rasa dan penerimaan keseluruhan donat serta berpengaruh tidak nyata terhadap aroma donat.

2. Perbandingan $60 \%$ terigu dan $40 \%$ puree buah naga merah dapat menghasilkan donat perbandingan terigu dan puree buah naga merah dengan karakteristik terbaik yaitu kadar air $23,17 \%$, total antosianin $12,85 \mathrm{mg} / 100 \mathrm{~g}, \quad$ aktivitas antioksidan $64,58 \%$, nilai ( $\mathrm{L}^{*}$ ) yaitu 31,13, (a*) yaitu 41,43, (b*) yaitu 14,33, warna (suka dan sangat merah), tekstur (suka dan sangat lembut), rasa (suka), aroma (suka) dan penerimaan keseluruhan (suka).

\section{Saran}

Berdasarkan penelitian yang telah dilakukan dapat disarankan dalam proses pembuatan donat menggunakan perbandingan $60 \%$ terigu dan $40 \%$ puree buah naga merah sehingga menghasilkan donat dengan karakterisik terbaik. 


\section{DAFTAR PUSTKA}

Agustin, V., M. Sugitha., dan P. A. Sandhi. 2017. Pengaruh perbandingan terigu dengan puree labu kuning (Cucurbita moschata ex, Poir) terhadap karakteristik kue lumpur. Program Studi Ilmu dan Teknologi Pangan. Fakultas Teknologi Pertanian. Universitas Udayana. Bali. Jurnal ITEPA Vol. 6 (2): 11-20.

Akbar, B. 1994. Pengaruh Penambahan Xanthan Gum dan Substitusi Parsial Tepung Gandum dengan Tepung Campuran dalam Pembuatan Roti Tawar. Skripsi. Teknologi Industri Pertanian. Institut Pertanian Bogor. Bogor.

Anonimus. 1994. Mutu Margarin. Standar Nasional Indonesia (SNI) 01-3541-1994. Badan Standarisasi Nasional. Jakarta.

Anonimus. $2019 . \quad$ Yeast. https://m.joyofbaking.com.

Diakses tanggal 23 Juni 2019.

Association of Official Analytical Chemist (AOAC). 2006. Official Methods of AOAC International. Revisi ke-2. Vol ke-1. Maryland (US): Association of Official Analytical Chemist.

Astawan, M. 2006. Sehat dengan Tepung Terigu. Dian Rakyat. Jakarta.

Badan Standart Nasional. 2000. Standar Nasional Indonesia (SNI) 01-3741-2002. Syarat Mutu Minyak Goreng. BSN. Jakarta.

Badan Standart Nasional. 2009. Standar Nasional Indonesia
(SNI) 01-3751-2009. Syarat Mutu Terigu. BSN. Jakarta.

Cahyono, B. 2009. Buku Terlengkap Sukses Bertanam Buah Naga. Pustaka Mina. Jakarta.

Citramukti, I. 2008. Ekstraksi Dan Uji Kualitas Pigmen Antosianin Pada Kulit Buah Naga Merah (Hylocereus costaricensis), (Kajian Masa Simpan Buah Dan Penggunaan Jenis Pelarut). Skripsi. Jurusan Teknologi Hasil Pertanian. Universitas Muhammadiyah Malang. Malang.

Daniel, A. R. 1978. Bakery Materails and Methods. Applied Science Publisher. London.

Farikha, I. N. 2013. Pengaruh Jenis Dan Konsentrasi Bahan Penstabil Alami Terhadap Karakteristik Fisikokimia Sari Buah Naga Merah (Hylocereus polyrzhius) Selama Penyimpanan. Skripsi. Fakultas Pertanian. Universitas Sebelas Maret. Surakarta.

Fatmawati. 2017. Pengaruh Penambahan Puree Kulit Buah Naga (Hylocereus polyrhizus) Terhadap Karakteristik Permen Jelly (Annona muricata, L). Skripsi. Fakultas Teknologi Pertanian. Universitas Andalas. Padang.

Karlina, L. 2015. Pengaruh Substitusi Tepung Kentang dan Tepung Terigu Terhadap Karakteristik Donat. Skripsi. Program Ilmu dan Teknologi Pangan. Fakultas Pertanian. Universitas Sumatera Utara. Medan.

Ketaren, S. 2008. Pengantar Teknologi Minyak dan Lemak Pangan. UI 
Press. Jakarta.

Kisman, S., B. Anjasari., dan S. Sumiarsih. 2000. Pengaruh Jenis Pengisi dan Kadar Sukrosa Terhadap Mutu Dodol Susu Jerami Nangka. Pusat Kajian Makanan Tradisional. Universitas Brawijaya. Malang

Kristanto, D. 2013. Buah Naga Pembudidayaan di Pot dan di Kebun. Penebar Swadaya. Jakarta.

Gomez, K. A., dan A. A. Gomez. 1995. Prosedur Statistik Untuk Penelitian Pertanian. UI Press. Jakarta.

Jayanti, P. R., 2010. Kajian Kandungan Senyawa Fungsional dan Karakteristik Sensori Es Goyang Buah Naga Super Merah (Hylocereus costaricensis). Laporan Penelitian. Universitas Sebelas Maret. Surakarta.

Lee, J. 2005. Determination of total monomeric anthocyanin pigment content of fruit juice, beverages, natural colorants, and wines by the ph differential method: collaboration study. Journal of AOAC International. Vol. 88 (5): 1269-1278.

Matz. 1960. Bakery Technology and Engineering. First edition. The AVI Publishing Company. Wetsport. Connecticut. United States.

Molyneux, P. 2004. The use of the stable free radikal diphenyl picryl hydrazyl (DPPH) for estimating antioxidant activity. Journal Science of Technology. Vol 26 (2): 211-219.
Mudjajanto, E. S., dan L. N. Yulianti. 2004. Membuat Aneka Roti. Penebar Swadaya. Jakarta.

Nitasari, L. 2003. Proses Produksi Mie Instan dan Evaluasi Perencanaan Sanitasi Perusahaan di PT. Tiga Pilar Sejahtera. Universitas Gadjah Mada. Yogyakarta.

Putri, D. A., dan Murtini E. S. 2017. Potensi edamame sebagai pengganti kuning telur dalam pembuatan donat mengandung kentang. Fakultas Teknologi Pertanian. Universitas Brawijaya. Malang. Vol 28 (2) : 102-110.

Ridho, A. E. 2013. Uji Aktivitas Antioksidan Ekstrak Metanol Buah Lakum (Cayratia trifolia) dengan metode DPPH (2,2difenil-1-pikrilhidrazil). Naskah Publikasi. Program Studi Farmasi. Fakultas Kedokteran. Universitas Tanjungpura. Pontianak.

Rustandi, D. 2011. Produksi Mie. Tiga Serangkai Pustaka Mandiri. Solo.

Shah, P., dan H.A. Modi. 2015. Comparative study of DPPH, ABTS, and FRAP assays for determination of antioxidant activity. Internation journal for research in applied science \& engineering technology (ijraset). Vol 3 (4) : 636-641.

Shahidi, F. 2005. "Bailley's Industrial Oil And Fat Products". Sixth Edition. Wiley Interscience. A John Wiley \& Sons. Inc., Publication. New York.

Shahrirputra, A. A. 2019. Pengaruh Perbandingan Terigu dan Pasta Brokoli (Brassica oleraceae L.) 
Terhadap Karakteristik Donat. Skripsi. Program Studi Ilmu dan Teknologi Pangan. Fakultas Teknologi Pertanian. Universitas Udayana. Bali.

Soekarto, S.T. 1985. Penilaian Organoleptik Untuk Industri Pangan dan Pertanian. Bharata Karya Aksara. Jakarta.

Sugitha, I. M., dan I. W. R. Widarta. 2012. Teknologi Susu, Daging, dan Telur. Buku Arti. Denpasar.

Subarna. 1992. Baking Technology. Pelatihan Singkat Prinsip-prinsip Teknologi Bagi Food Inspector. Pusat Antar Universitas Pangan dan Gizi. Institut Pertanian Bogor. Bogor.

Syarbini, H. M. 2013. A-Z Bakery. Metagraf. Solo.

Taiwan Food Industry Development and Research Authorities. 2005. Dragon

Fruit. http://swarnabhuni.com. Diakses tanggal 23 Juni 2019.

Vargas, M., J. A. T. Cortez., E. S. Duch., A. D. Lizama., and C. H. H. Mendez. 2013. Extraction and stability of anthocyanin present in the skin of the dragon fruit (Hylocereus undatus). Food and Nutrition Sciences. 4: 12211228.

Widianingsih, M. 2016. Antioxidant activity extract methanol of red dragon fruit (Hylocereus polyrhizus) obtained maceration and evaporation by dry air. Jurnal Wiyata. Vol. 3 (2) : 1316.

Winarno, F. G. 1992. Kimia Pangan Dan Gizi. PT. Gramedia Pustaka Utama. Jakarta.
Winarsih, S. 2007. Mengenal dan Membudidayakan Buah Naga. CV Aneka Ilmu. Semarang.

Yahyono, S. S. 1999. Kreasi Roti. PT Gramedia Pustaka Utama, anggota IKAPI. Jakarta.

Yunita, S. 2015. Pengaruh Jumlah Pektin dan Gula Terhadap Sifat Organoleptik Jam Buah Naga Merah (Hylocereus polyrhizus). Skripsi. Program Studi Pendidikan Tata Boga. Fakultas Teknik. Universitas Negeri Surabaya. Surabaya.

Zuhrina. 2011. Pengaruh Penambahan Tepung Kulit Pisang Raja Terhadap Daya Terima Kue Donat. Skripsi. Fakultas Kesehatan Masyarakat. Universitas Sumatera Utara. Medan. 